\title{
The petrogenesis of a crustal-derived Palaeoproterozoic Bomdila orthogneiss, Arunachal Pradesh, NE Lesser Himalaya
}

\author{
Shaik A Rashid \\ Department of Geology, Aligarh Muslim University, Aligarh - 202002, INDIA \\ E-mail: rashidamu@hotmail.com
}

The major and trace element geochemistry of the Paleoproterozoic Bomdila orthogneisses from the Arunachal Pradesh, NE Lesser Himalaya has been determined to understand their nature and petrogenetic processes. Rigorous field and mineralogical examinations have indicated that the Bomdila gneisses consists of two types of granitic phases; a coarse-grained porphyritic gneiss (CPG) comprising of biotite and muscovite with the spectacular absence of tourmaline (referred as two-mica granites or tourmalinefree granites) and a weakly to non-foliated leucogranite having abundant tourmaline (referred as tourmaline-bearing granite). All the Bomdila samples have high $\mathrm{Al}_{2} \mathrm{O}_{3}$ (>13wt.\%), with molar A/CNK $\left(\mathrm{Al}_{2} \mathrm{O}_{3} / \mathrm{CaO}+\mathrm{Na}_{2} \mathrm{O}+\mathrm{K}_{2} \mathrm{O}\right)>1.1$ and normative corundum indicating a high peraluminosity and $\mathrm{S}$-type nature of these granites. They are enriched in incompatible elements such as $\mathrm{Rb}, \mathrm{Ba}, \mathrm{K}$ and $\mathrm{Th}$ and depleted in high field strength elements (HFSE) like $\mathrm{Zr}$, Hf, $\mathrm{Ta}$ and $\mathrm{Nb}$. The two-mica granites show higher Rare Earth Elements (REE) concentrations (sum up to $294 \mathrm{ppm}$ ) than the tourmaline granites (sum $=67 \mathrm{ppm}$ ). Both the phases reveal a LREE enriched and flat HREE patterns with negative Eu anomalies. The enrichment of the Bomdila gneisses in the incompatible elements and depletion in the HFSE strongly supports their postulated crustal source. Both the granite suits are characterized by high incompatible elements/HFSE ratios, which is in agreement with many intracrustally derived granites. Tourmaline-bearing granites are clearly distinguished by their low $\mathrm{Sr}$ and $\mathrm{Ba}$ contents compared with the tourmaline-free facies and are generally depleted in $\mathrm{Zr}$ and $\mathrm{Nb}$. The tourmaline granites of the Bomdila massif generally lie within the syn-collision field (as do other Himalayan leucogranites) in the discriminant $\mathrm{Rb}$ vs. ( $\mathrm{Nb}$ $+\mathrm{Y}$ ) diagram whereas the two-mica granites straddles the field boundary between collision granite and volcanic-arc granite. The peraluminous geochemistry and phase equilibria conditions of the tourmaline-free granites indicate that they have been derived from the biotite-limited, vapour-absent biotite dehydration melting of a pelitic source rock. The aluminous chemistry, low $\mathrm{Fe}_{2} \mathrm{O}_{3}+$ $\mathrm{MgO}$ values $(<2)$ and the presence of tourmaline emphasize that the tourmaline granites may have been derived from dehydration melting of muscovite higher in the crustal levels. 